\title{
Are Public Libraries a Commonplace? Users from Disadvantaged Groups, Their Cultural Participation Models and an Impact of Libraries
}

Abstract

In the article, I presented the results of the study of the social impact of Mazovian public libraries, focusing on groups of users coming from disadvantaged backgrounds - older people, people in the worse financial situation and residents of villages and small towns. Surveys were carried out in 2017 on 1098 users of 38 Mazovian public libraries (rural and urban). Based on the data I concluded that there are some differences both in the models of public libraries' use in the analyzed groups, as well as in the range of the benefits of contact with libraries.

Key words: cultural institutions, institutional culture, library users, public libraries, social impact

Słowa kluczowe: biblioteki publiczne, instytucje kultury, kultura instytucjonalna, użytkownicy bibliotek, wpływ społeczny

\section{Introduction}

In 2018, in the Forbes magazine, the text by Panos Mourdoukoutas titled Amazon Should Replace Local Libraries to Save Taxpayers Money was published, in which the author postulated closing of all libraries and redirecting funds previously dedicated to their maintenance to purchase access to the Amazon's services [Mourdoukoutas 2018]. This text was withdrawn by the editors who also published a correction 
[Ha 2018]. But the question 'why are there libraries at all?' reveals the tension between a rational economic order, emotional attachment to the cultural value of libraries as heritage treasuries and social demand for equal access to culture and knowledge. In this text, I would like to try to answer the question of what people do in libraries and what it gives them in the context of disadvantaged groups, which are likely to suffer the most if the libraries were replaced by an international corporation's services. The article is also an attempt to deepen the perspective on participation in culture through public libraries.

\section{Literature review}

Andrzej Tyszka distinguished seven aspects of the meaning of participation in culture:

- semiotic - referring to the social communication process through signs and sign systems,

- hermeneutic - connected with the ability to read and give meaning to information messages and symbolic products through their understanding interpretation,

- axiological - referring to values, their orders and established ways of valuation,

- normative-steering - within which knowledge of norms and patterns and their regulating influence on behaviour are important,

- psychological - associated with personality traits and skills, reception and expression of cultural content that become part of life,

- gnostic - referring to the resource and organization of information enabling orientation towards experiences, especially symbolic ones,

- sociological - the sphere of symbolic identification with the group and position in the group, and a community of values ensuring integration in action [Tyszka 1981: 142].

The study of participation in culture is associated with several practical difficulties (the scope and method of data collection) and conceptual problems, above all:

- divisions for 'high' and 'low' culture, additionally with unclear boundaries,

- divisions for the administrators and recipients of culture, which in the modern networked societies is becoming increasingly blurred,

- divisions for active and passive participation in culture,

- valuing a priori forms and content of participation in culture [Fatyga 2014].

Despite these reservations, the authors of the report "Cultural practices of Poles" postulate, however, not to abandon the concept of participation in culture, but to approach it critically and reformulate as 'participation in a certain relationship characteristic for a given community' [Krajewski 2014: 16-18]. 
Public libraries, on the one hand, function within the institutional culture [Knaś 2012], on the other, they are undergoing a series of changes in recent years, aimed at including user groups in designing space and services and democratizing relationships on the librarian-user line. This trend formerly referred to as the library 2.0 [Casey, Savastinuk 2006], is increasingly called 'a participatory library' [Nguyen et al. 2012]. Based on my research, I argue that in fact the use of libraries, especially small units, leads to the creation of some kind of relation, sometimes very complex, in which the user is an autonomous and active entity [Paul 2018a].

As the basis for further considerations, let's check what we know and what we do not know about participation in culture through public libraries. Central Statistical Office data indicate that since the 1990s, both the number of libraries and people using them decrease slightly in comparison year-on-year, but systematically. In 1995, there were over 9505 libraries and library branches in Poland, and 7953 in 2017 [Główny Urząd Statystyczny 2019]. First and foremost, library branches, especially common in rural areas, are being closed or included in other institutions [Budyńska, Jezierska 2018]. Compare chart 1.

In the years 1995-2017, the number of users decreased from slightly above 7 to slightly more than 6 million (chart 1). The number of users per 100 inhabitants is currently around $15,7^{1}$ and there is also a downward trend. Since the 1990s, libraries have lost almost a quarter of the audience. In 2017, approximately 73 million visits were registered in public libraries, of which $71 \%$ in cities, although libraries in urban areas constitute $35 \%$ of the network. This, of course, is related to the time and physical availability of individual units, the attractiveness of the collections and the size of the population served [Budyńska, Jezierska 2018; Biblioteka Narodowa 2018].

The structure of library users differs slightly from the structure of the inhabitants of Poland. There are more people in the group aged between 6 and 24 than in the population of Poles. The largest groups of users are people aged 25-44, then 6-12 and 45-60 years. It seems, therefore, that using libraries is conducive to being a student as well as a professional activity. The detailed age structure of users and a comparison with the structure of Polish residents are presented in Table 1.

According to the latest readership survey carried out in 2018, at the request of the National Library, during the year preceding the study, 37\% of Poles read at least one book and this is a trend that has been going on for years. Books are more often

1 In the cited report 'Cultural practices of Poles' cite, the percentage of library users amounted to $38,4 \%$. Differences may result from surveys' sample selection, the specificity of the question asked, which the authors mention at pages 148 and 153, but also inaccuracies or errors in the collection of library statistics (eg. errors in library systems) and also sharing one library account by several people, family or friends and using libraries by proxy (eg. borrowing books for less mobile people). 


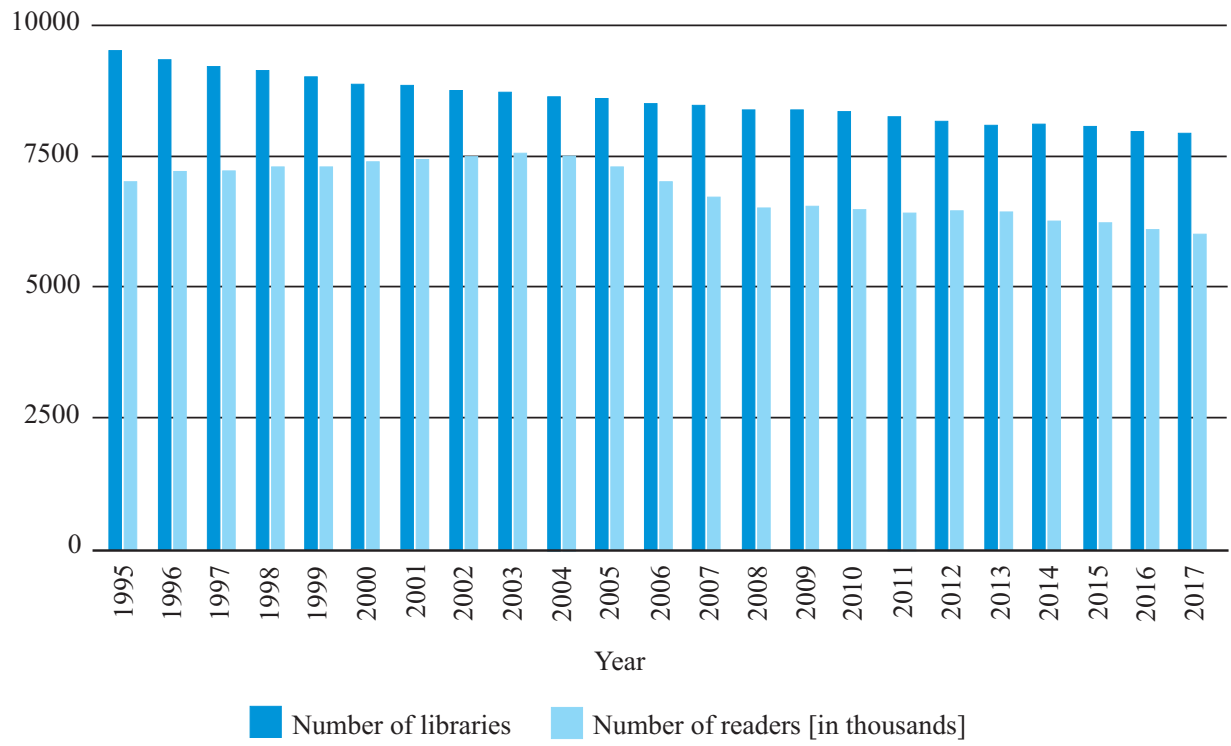

Chart 1. The decrease in the number of public libraries and their users

Source: Główny Urząd Statystyczny [2019].

read by women and young people, who are still learning. Survey also tells us about the sources of books - they were borrowed in public libraries by around $16 \%$ of respondents. Librarians are also not the basic source of information and opinions about what is worth reading (friends and family are essential, but above all, self-assessment is important) - for younger groups (up to 39 years old), their opinion is less important than posted on the internet [Koryś, Chymkowski 2019].

In previous analyses of the National Library, we can find data giving even more food for thought. In 2016, respondents were asked, 'If a public library were closed near you, would it have a major influence, little influence or no influence on your family and yours?' Only $15 \%$ of respondents answered that it would have a big impact on them, and $26 \%$ - a small impact. Half of the respondents believed that it would not cause any change in their lives [Biblioteka Narodowa 2017: 60]. For comparison, in a study conducted in the United States [Zickuhr et al. 2013: 20] and Italy [Chiessi 2011:25], the percentage of people stating that the closure of the library would affect them was almost $90 \%$.

Studies performed in a situation of planning [Frederiksen 2015], temporary closure [Usherwood 2002] or permanent liquidation of libraries [Koontz et al. 2009] indicate first that the libraries were underestimated before its closure and that these institutions significantly contribute to the improvement of the quality of life. Secondly, the negative impact mainly affects disadvantaged groups, such as 
children, the elderly (less mobility, which makes it impossible to find an alternative to library services), people with lower education and financially vulnerable, as well as women.

Table 1. Structure of public libraries' users by age (2017)

\begin{tabular}{|l|c|c|c|}
\hline \multicolumn{1}{|c|}{ Age } & $\begin{array}{c}\text { Number of the rea- } \\
\text { ders/users }\end{array}$ & $\begin{array}{c}\text { Percentage of the age } \\
\text { group among all users }\end{array}$ & $\begin{array}{c}\text { Percentage of the age group } \\
\text { among all the residents of } \\
\text { Poland }\end{array}$ \\
\hline Up to 5 years & 161205 & 2,7 & 5,9 \\
\hline $6-12$ years & 960823 & 16,0 & 7,4 \\
\hline $13-15$ years & 438171 & 7,3 & 2,8 \\
\hline $16-19$ years & 484207 & 8,0 & 3,9 \\
\hline 20-24 years & 499340 & 8,3 & 5,7 \\
\hline $25-44$ years & 1707757 & 28,4 & 30,9 \\
\hline $45-60$ years & 965755 & 16,0 & 20,6 \\
\hline More than 60 years & 803408 & 13,3 & 22,7 \\
\hline In all & 6020666 & 100,0 & 100,0 \\
\hline
\end{tabular}

Source: based on Budyńska, Jezierska [2018].

It is often stated that the social role of public libraries is one of the most important and the oldest [Drzewiecki 2011]. Great Britain is an often-cited example, where social equality was one of the ideological foundations for public libraries in the $19^{\text {th }}$ century [Birdi et al. 2008; Williamson 2000]. Social inclusion was embodied in the concept of community librarianship, eg. 1980s' outreach, housebound services and specialization of services towards disadvantaged groups. On the other hand since its beginning till today this trend rivals with a 'universality' concept of libraries services which might be largely shaped (cost-effectiveness requirement and mainstream audience needs) and which benefits mostly the middle class [Birdi et al. 2008: 580-584; Muddiman et al. 2000: 12-16]. Given all historical differences, there are some similarities here as to the development of the concept of librarianship in Poland and the impact of political and economic transformation on libraries.

Several authors [Birdi et al. 2008; Gehner 2010; Muddiman et al. 2000: 17-18] emphasize that staffing reflecting the social structure and emphatic attitude of librarians themselves is important for inclusiveness. On the other hand, the culture of libraries itself (of which silence is an element - in other cases, as Pugacewicz 
[2017] points out, with extremely positive results) may be the reason for feeling unwelcomed and alienated in public libraries by groups such as young people, immigrants, the working class [DeFaveri 2005]. "In some cases, the very word 'library' is a deterrent to non-users and a symbol of a traditional, middle class alien culture" [Muddiman et al. 2000: 18].

The results of the discussed research indicate that the activity of public libraries is particularly important for disadvantaged groups, for which they are sometimes the only point of access to information, education, and culture. In Polish literature, this subject is still rarely raised, however the latest report on participation in the culture of Warsaw residents shows a fairly strong relationship between education and social class and the use of district public libraries - the higher education and class, the higher the probability of using library [Kotnarowski, Piechocki 2019: 45-47]. An earlier qualitative study conducted in Warsaw libraries also suggests the existence of various barriers - institutional and cultural - that can make people from disadvantaged groups not use public libraries or do not treat them as their place, as a commonplace [Chymkowski et al. 2017]. In the following text, I would like to deepen the perspective of using libraries and its effects by representatives of disadvantaged groups: seniors, people in a difficult financial situation and living in rural areas or small towns.

\section{Data and analysis methods}

The described study was a part of a research project that I carried out as my doctoral dissertation [Paul 2018b]. Between February and June 2017, I surveyed a sample of adult users of 38 Mazovian public libraries. Sampling was limited to people who used the library at the time of the study. Municipal libraries were drawn taking into account the proportion between the number of cities with a given number of inhabitants in the Mazovian Voivodeship. Table 2 presents the sample concerning the division into the size of the town. It also contains information on how many libraries from the town in a given size range I have collected data.

I collected the data using the auditorium questionnaire. Respondents self-filled surveys during their visit to the public library. The advantages of this solution are low cost, full anonymity and no influence of the interviewer, time for the respondent to think about the answer. However, for more difficult questions, the answers may be omitted or incorrect. There is also no control over who actually gives answers. Additionally, to increase the return of questionnaires in the case of Warsaw residents, I collected a number of questionnaires using the PAPI method, which provides greater return and control, but at the cost of anonymity and increased influence of the interviewer [Rószkiewicz et al. 2013: 133-134]. Unfortunately, the described method of data collection is associated with the risk of unrepresentativeness of the 
sample. The sample of this study is not representative in relation to the population of public library users in the Mazovian Voivodeship in terms of the type of place of residence and age. For this reason, as well as the exploratory nature of the research, I describe the sample, without concluding about the population.

Table 2. Structure of the sample in terms of the size of the place of residence

\begin{tabular}{|l|c|c|c|}
\hline $\begin{array}{c}\text { Size of the place of residence - the } \\
\text { number of inhabitants }\end{array}$ & $\begin{array}{c}\text { The number of libraries par- } \\
\text { ticipating in the study }\end{array}$ & N & P \\
\hline City over 500 thousand residents & 11 district libraries & 514 & 47,7 \\
\hline City 50-500 thousand residents & 4 & 127 & 11,8 \\
\hline City 20-50 thousand residents & 5 & 90 & 6,5 \\
\hline City 10-20 thousand residents & 6 & 119 & 11,0 \\
\hline City up to 10 thousand residents & 6 & 140 & 13,0 \\
\hline Village & 6 & $\mathbf{1 0 9 8}$ & $\mathbf{1 0 0 , 0}$ \\
\hline In all & 38 & 108,0 \\
\hline
\end{tabular}

Source: based on Paul (2018b).

In the study, I used the questionnaire prepared for this purpose. Respondents answered four questions and filled out the particulars. The first question concerned the frequency of using public libraries in the last twelve months. The second question also concerned the use of libraries, but other than the one in which the probe took place. The third question referred to activities carried out in libraries. Respondents indicated whether they were performing activities from the presented twenty-three-point list. The fourth question raised the issue of the benefits of using public libraries over the last twelve months. The respondents were presented with a closed list of fifteen benefits formulated as sentences, eg. 'I deepened my knowledge.' The questionnaire included questions about gender, year of birth, assessment of one's financial situation and the number of people in the household. There was also a section on the use of cultural institutions and media. The above scheme of the questionnaire made it possible to find answers to the research questions. The relationship between research questions, analyzed variables and survey questions are presented in Table 3.

I constructed the questionnaire based on the subject literature, statements of interviewees during individual interviews held before quantitative part of the research and the results of a research workshop with librarians of Warsaw public libraries, 
which I carried out in December 2016. In February 2017, I conducted a pilot survey in one of Warsaw's public libraries.

Table 3. The relationship between variables, research questions, and questionnaire questions

\begin{tabular}{|l|l|l|}
\hline \multicolumn{1}{|c|}{ Variable } & \multicolumn{1}{c|}{ Research question } & \multicolumn{1}{c|}{ Survey question } \\
\hline $\begin{array}{l}\text { Activities carried out in pub- } \\
\text { lic libraries }\end{array}$ & How do users use public libraries? & Q. 3.1. - Q.3.23. \\
\hline Benefits felt by users & $\begin{array}{l}\text { What benefits do they experience as } \\
\text { a result of using public libraries? }\end{array}$ & Q. 4.1. - Q. 4.15. \\
\hline Using public libraries & $\begin{array}{l}\text { How often do they use public libraries? } \\
\text { What other libraries do they use? }\end{array}$ & Q. 1 \& Q. 2 \\
\hline Using cultural institutions & $\begin{array}{l}\text { Which other than the libraries cultural } \\
\text { institutions do they use? }\end{array}$ & P. 3.1. - P. 3.7. \\
\hline Using the media & $\begin{array}{l}\text { What media do they use? How much } \\
\text { time do they devote to it? }\end{array}$ & P. 4.1. - P. 4.5. \\
\hline $\begin{array}{l}\text { Gender, age, financial situa- } \\
\text { tion, size of the household, } \\
\text { size of the place of residency }\end{array}$ & $\begin{array}{l}\text { What factors influence the use of librar- } \\
\text { ies? What factors affect the perception } \\
\text { of benefits from public libraries? }\end{array}$ & $\begin{array}{l}\text { P. 1., P. 2, P. 5., P. 6., the size } \\
\text { of the city of residence was } \\
\text { assumed to be the same size as } \\
\text { the city where the library was } \\
\text { located, where the survey was } \\
\text { conducted }\end{array}$ \\
\hline
\end{tabular}

Source: based on Paul (2018b).

In the study, I used statistical distributions and frequency as well as descriptive statistics. To determine the relationship between variables I used the chi-square test. In the case of explained variables presented on the strong scales, the method of comparing averages (regression of averages) in subgroups was used [Lissowski et al. 2011].

\section{Results}

\section{Disadvantaged groups characteristic and participation in culture}

As I mentioned, the survey was conducted on a sample of 1098 people. The seniors (60 years or more) constituted $23 \%$ of the studied group $(\mathrm{N}=255)$, people with a difficult financial situation $7 \%(\mathrm{~N}=76)$, and residents of villages and towns up to 10,000 residents also approx. $23 \%(\mathrm{~N}=248)$. Partially, these groups overlap and so it can be stated that: $15 \%$ of answers came from seniors living in the countryside and $12 \%$ of people 60 years or older declared that they were in 
a difficult financial situation. Seniors accounted for $16 \%$, and poor people $-5 \%$ of surveyed library users in small towns and villages. Of those in a difficult financial situation, $40 \%$ were 60 or over and $17 \%$ lived in the countryside. What should be emphasized - women dominated in each group, because according to other data and as confirmed in the study - they are the major group of public library users. In the study group, age positively correlates with the size of the place of residence $\left(\rho_{s}=0,131\right)$, which may indicate that seniors in larger towns have greater access to libraries; and negatively with the financial situation $\left(\rho_{s}=-0,064\right)$. The correlation between the size of the place of residence and the financial situation was not statistically significant. The detailed distribution of the sample in the division of the age, the assessment of the financial situation and the size of the place of residence are presented in Chart 2.

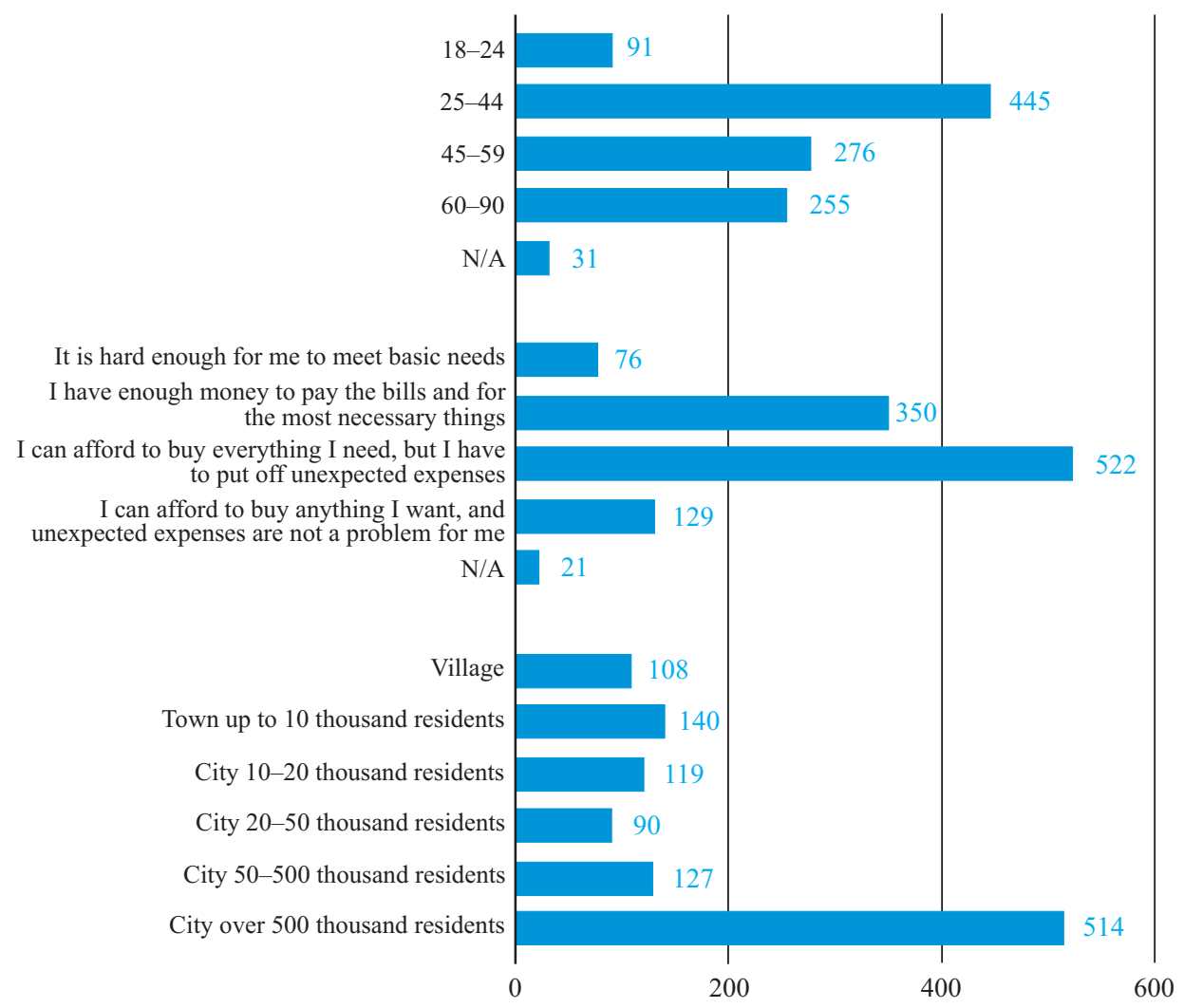

Chart 2. The demographic and social structure of the sample $(N=1098)$

Source: based on survey data. 
The average respondent visited 2,9 cultural institutions other than libraries within the three months preceding the survey. For seniors, this indicator was only slightly lower $-2,85$. Statistically significant differences can be seen in the case of residents of small towns and villages $-2,6$, and the gap between poor people is particularly high $(\mathrm{M}=2,2)$.

It is worth taking a look at the differences in the use of various types of cultural institutions. The seniors went to the cinema and artistic or cultural festivals much less frequently than the rest of the surveyed group, while more often they declared going to the theatre or philharmonic. People in a difficult situation generally less often used cultural institutions, in particular, differences can be seen in the case of cinema and theatre or philharmonic, which could be influenced by their financial unavailability. Similarly, in the case of people from small towns, they also rarely went to museums or galleries, which is probably also connected with the distance to these places. Differences are illustrated in Chart 3.

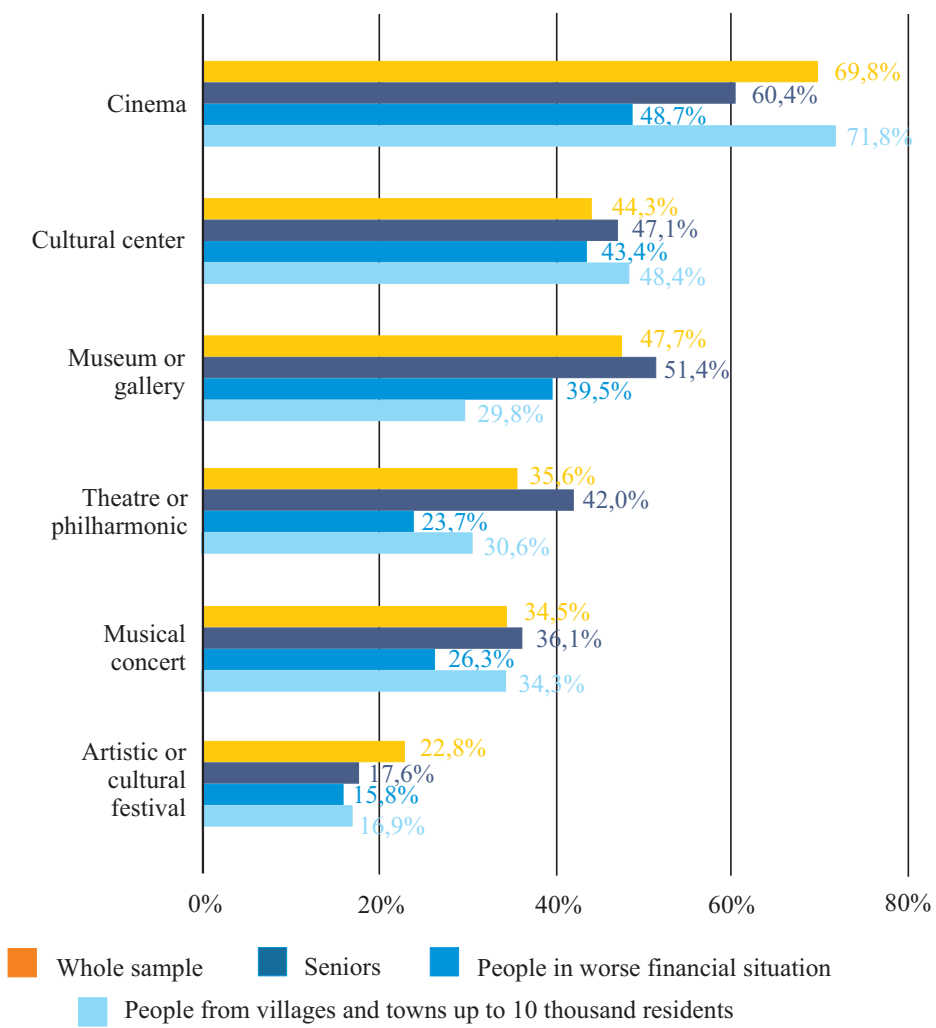

Chart 3. Using cultural institutions by representatives of disadvantaged groups Source: based on survey data. 
Respondents were also asked about using the media in the week preceding the survey. The average time of using the media in the sample amounted to 40,1 hours (about 5,7 hours per day), including approx. 12,5 hours for books and press, and about 27,8 hours for other media. When reading this data, we must remember that some of the media can be received simultaneously with other daily activities (eg. listening to the radio on the way to or while working) or even simultaneously with each other (reading a book when the television is 'in the background').

Considering particular types of media, seniors used all of them much more often than the rest of the sample, except the Internet $(M=11,1$ hours for all respondents, 7,2 in the subgroup of older people). The use of media by people in a difficult financial situation was not much different from the rest of the surveyed group - differences are not statistically significant except for the Internet, which was used 4,2 hours a week less often. Also, people from villages and small towns were less likely to use the media, especially books, the press, and the Internet. Differences and average cumulative time in subgroups are shown in Chart 4.

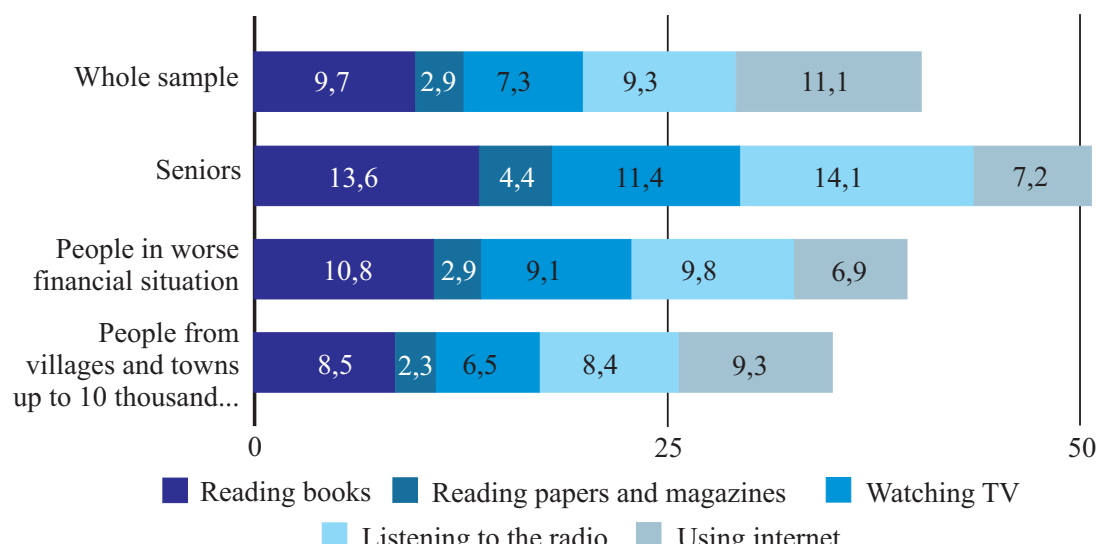

Chart 4. Average time of using the media by representatives of disadvantaged groups (in hours per week)

Source: based on survey data.

\section{Public libraries' usage}

In general, users often used public library services - $87 \%$ declared that they had visited them at least several times a month during the year preceding the survey. In this context it's worth to recall the statement by Tomasz Goban-Klas regarding the study of the audience and the media public: 
The rule is that the proportion of people using a given type of media more often than the average is greater in the individual audience than in the public. Conversely, the proportion of people using relatively less frequently than others is less in the audience than in the public. This means that by examining (...) the audience, we will overestimate the share of people, who use it more often, underestimating the share of people using it less frequently [Goban-Klas 2009: 220].

The author emphasizes the special importance of tracking the distributions of socio-demographic variables. Let's check then how the analyzed subgroups tend to use public libraries.

The seniors were even more likely to use public libraries than the total sample. A subgroup that uses several times a month is especially numerous. It can be combined with the more free time they have as mostly non-working people. In turn, people living in the villages and small towns seem to use libraries less frequently than the rest of the respondents - the subgroup of people using it once a month is more numerous than in the rest of the sample. Here, in turn, the reason may be less availability of libraries in these areas. Frequency of using libraries by people in financial difficulties is not significantly different from the rest of the sample. The distributions and differences between them are shown in Chart 5.

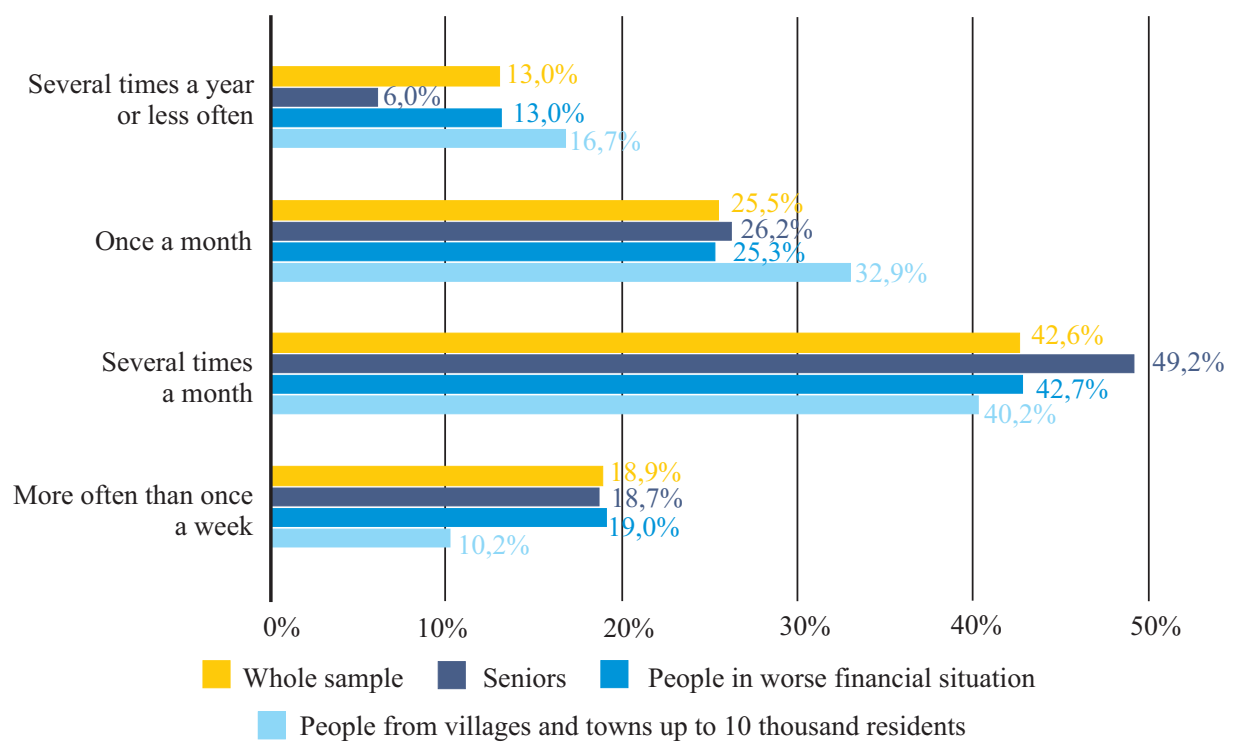

Chart 5. Frequency of using public libraries by representatives of disadvantaged groups Source: based on survey data. 
As I mentioned earlier, the use of libraries is not only about borrowing books, although it remains the library activity most often performed in libraries. It was performed by almost 95\% of surveyed users - people from small towns much more often than the rest of the sample, and people in a difficult financial situation less often. The latter, however, significantly more often used library materials on the spot (in contrast to seniors, in turn). Meanwhile, seniors less often than the rest of the sample used audiobooks, e-books, and audio-visual materials. Libraries are also a place where the life of the local community is going on. Seniors and poor people met or spent time with friends there. The seniors also watched the exhibition's libraries slightly more often. Public libraries are also one of the free, and thanks to numerous programs, a well-equipped ICT access point. The seniors less frequently than other users used computers, the Internet and other office equipment. The latter, on the other hand, were more often used by people in worse financial situation.

The use of libraries by residents of villages and small towns was sometimes more similar to the inhabitants of medium and large cities, and at other times similar to the models of use of Warsaw users. People from villages and towns significantly more often than Warsaw residents: borrowed books, talked with librarians or other users, met with friends, participated in author meetings, used computers, the Internet and office equipment. Significantly less often than residents of medium-sized towns, they read books and press on the spot and voted in libraries in the participatory budget (since it is implemented in larger towns).

In the case of the other activities studied, I did not observe any major differences. Detailed frequencies are shown in Chart 6.

Taking into account the number of library activities performed by the total sample $(M=6,7)$ and individual subgroups of respondents, it can be seen that seniors $(6,6)$ and people from small towns $(6,1)$ were only slightly less active ${ }^{2}$. In general, seniors were less likely than other users to use library materials and ICT tools, but they were more often involved in the social and cultural life of libraries. Differences between residents of small towns and the rest of the sample relate to activities related to learning and work and social and cultural life - on average, they did less activity in these areas. The distributions and differences can be seen in Chart 7.

The last issue that I would like to address is the matter of benefits experienced by users as a result of contact with public libraries. Generally, the differences between the number of perceived benefits between individual subgroups and the total sample (on average, all persons agreed with presented 7,7 statements) were small

2 In the case of people in a difficult financial situation, the results were statistically insignificant, which is probably due to the small size of this group. 


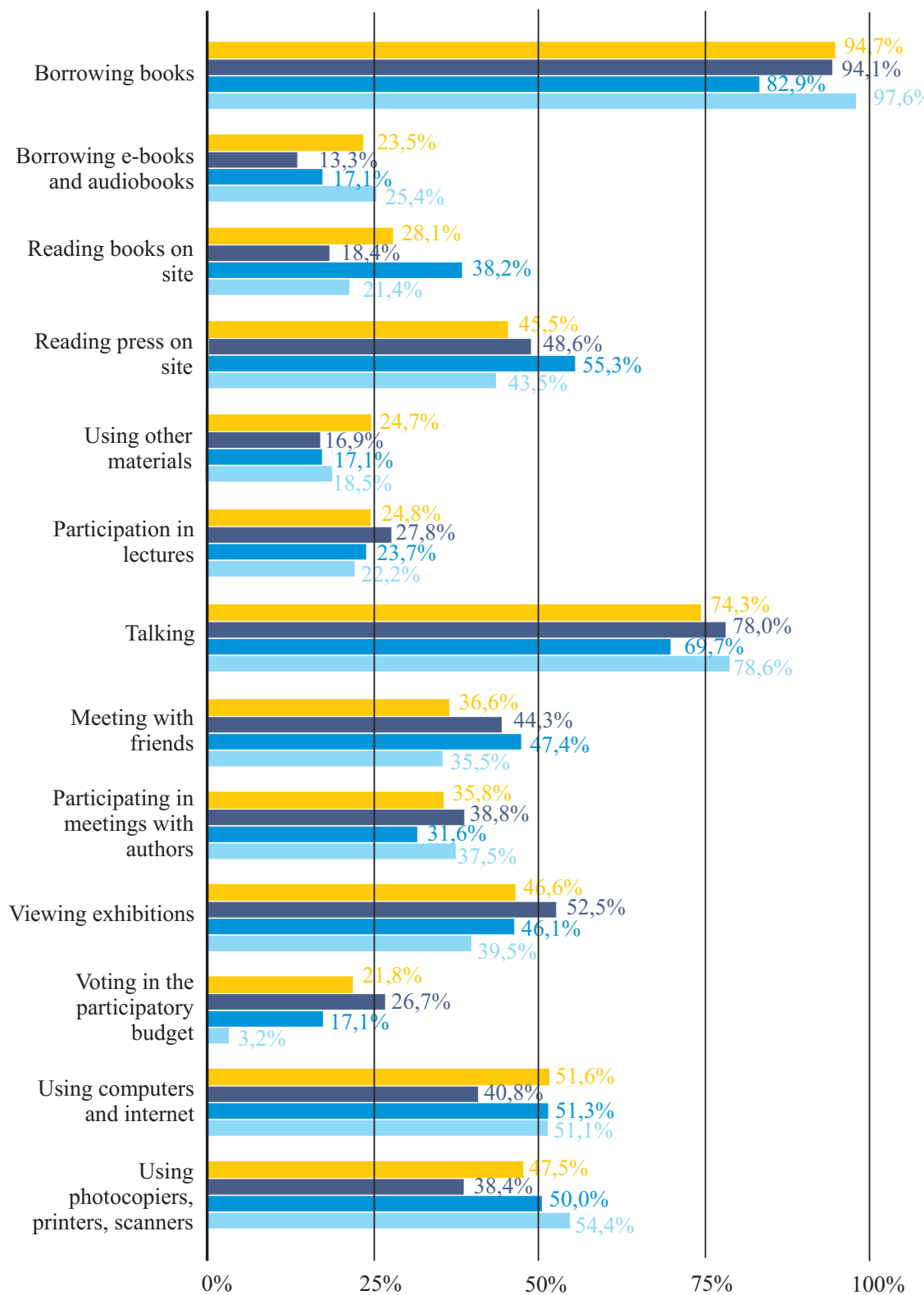

Whole sample

Seniors

People in worse financial situation

People from villages and towns up to 10 thousand residents

Chart 6. Library activities by representatives of disadvantaged groups(frequencies for 13 most popular activities; P > 20\%)

Source: based on survey data. 


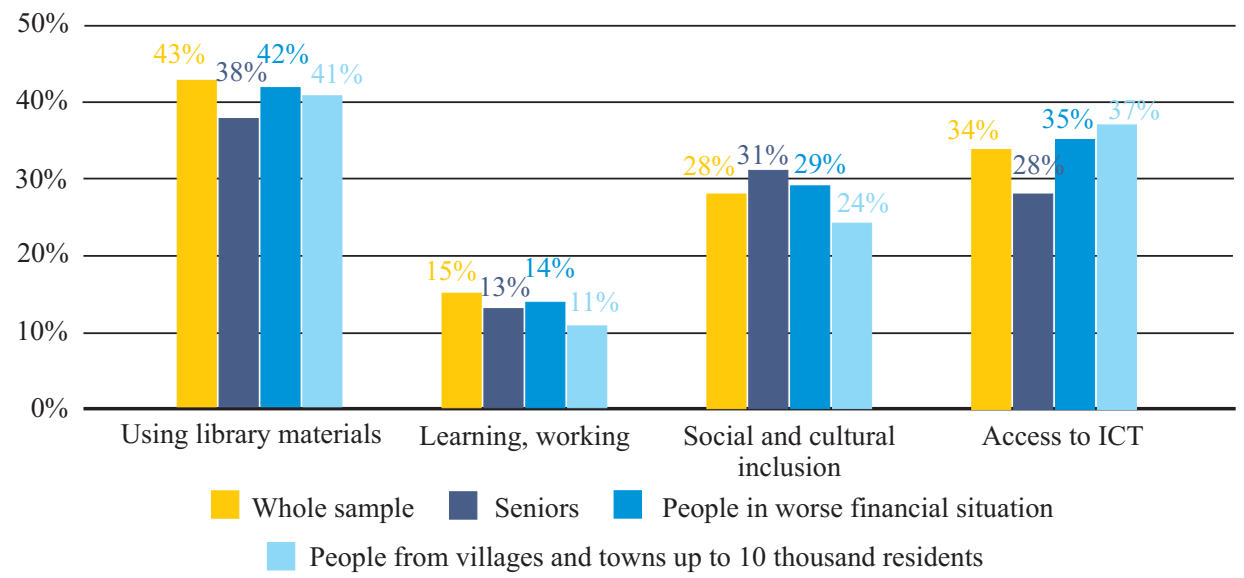

Chart 7. Areas of library activity by subgroups of users

Source: based on survey data.

- seniors experienced an average of 7,5 benefits, poorer people - 7,9, and people from villages and small towns $-7,4$.

There are some differences in the types of benefits experienced by the subgroups of the respondents ${ }^{3}$. People from villages and small towns more often than the rest of the sample declared that thanks to contacts with libraries their results in learning and working improved, they acquired new skills and exchanged experiences with other people. In turn, seniors less often recognized that libraries helped them to meet information needs (finding information, using inaccessible materials, acquiring skills), more often they mentioned the benefits of their well-being - libraries allowed them to de-stress, rest and gave entertainment and pleasure. This is probably related to the specific needs of the group at this age. The above differences, as well as similarities, are visible in Chart 8 .

3 I don't present data about a subgroup of people in the worse financial situation, because of the small sample amount some cells of the table had numbers lower than expected, which resulted in the irrelevance of the chi-square test. 


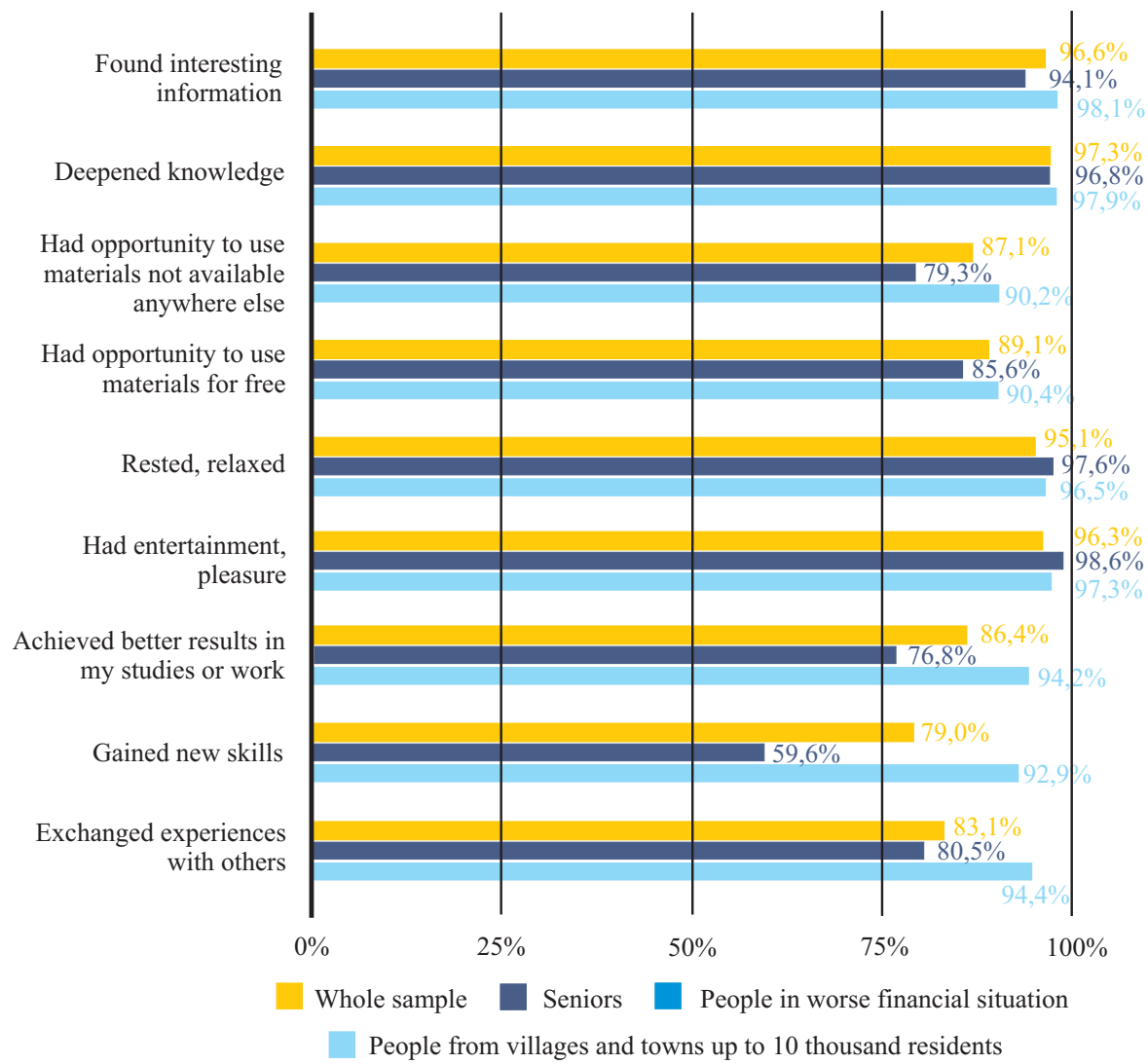

Chart 8. Benefits resulting from contacts with libraries divided into subgroups of users (for variables of which $\mathrm{Me}=1$ )

Source: based on survey data.

\section{Discussion}

Presented data and outcomes give more in-depth information about libraries users activity and the impact of public libraries than traditional libraries' assessment methods, ie. statistics and performance measures. It shows:

- the whole spectrum of library activities, thanks to the fact that the research does not focus exclusively on traditional library services,

- not only the potential of libraries (eg. the size of the book collection per 1000 people served to the public) but their actual use by specific users,

- the importance of gathering comprehensive data, which allows for subgroup analysis and determination of dependencies between variables. 
The survey illustrates that libraries are not just lending and reading rooms, that users are eager to use the proposed peripheral activities. However, even the very use of books (also press and materials in other forms) can have an added value, like the entire library activity.

Value addition takes place in the course of various library processes, not only service ones. These are the processes of collecting, archiving, developing and appropriately organizing information resources and facilities. Also: organization of access, sharing, use, and supplementation, as well as the promotion of various content. And there are also mentioned the processes of preparing communication public and organization of public space to enable local contacts (...). It is an extended, strategic formula of library mediation in public communication, which also has this unique feature that is unpaid [Wojciechowski 2005: 19].

The presented approach, although quantitative, introduces the user's perspective to research on public libraries. The assessment of the units is made not based on the performance of planned indicators, but on the basis of whether the library satisfies the various needs of users.

The main issue of the study is a non-representativeness of the sample. I think, however, that this weakness was partially overcome by the fact that I focused on using smaller local libraries (Warsaw districts libraries and most urban libraries were also small institutions) because they constitute the majority of the library network.

In this text, I focused on groups considered disadvantaged - older people, in a difficult financial situation and living in the villages and small towns. Although there are some statistically significant differences in the models of using public libraries and the benefits of library contacts between these subgroups and the rest of the sample, they are so small that it is difficult to talk about the systematic exclusion of analyzed communities due to age, financial status, place of residence - or, more broadly, social class.

Here, however, I need to make some important caveat - only active users were surveyed, so people, who overcame the potential barriers, reached the library and used its services. It can only be said that among users the differences are so small that they do not indicate the phenomenon of exclusion of disadvantaged groups. Only the analysis of the non-users, which I would like to undertake in the next study, is able to show if there are no barriers [as described in Muddiman et al. 2000 and others mentioned in earlier section] that make people from these environments do not even have the chance to reach libraries, their resources, and the additional offer. 


\section{Bibliogipaphy}

Biblioteka Narodowa (2017), Stan Czytelnictwa w Polsce w 2016 roku, Warszawa: Biblioteka Narodowa, http://www.bn.org.pl/download/document/1493378303.pdf [accessed: 6.06.2019].

Biblioteka Narodowa (2018), Zestawienie zbiorcze o stanie i działalności sieci bibliotek publicznych w 2017 r., Warszawa: Pracownia Bibliotekoznawstwa IKiCZ BN, https://www.bn.org. $\mathrm{pl} /$ download/document/1557307802.pdf [accessed: 6.06.2019].

Birdi B., Wilson K., Cocker J. (2008), The Public Library, Exclusion and Empathy: a Literature Review, "Library Review", Vol. 57, Issue 8, p. 576-592.

Budyńska B., Jezierska M. (2018), Stan bibliotek w Polsce objętych badaniem Głównego Urzędu Statystycznego - 2017 r., Warszawa: Pracownia Bibliotekoznawstwa IKiCZ BN, https:// www.bn.org.pl/download/document/1554115920.pdf [accessed: 6.06.2019].

Casey M.E., Savastinuk L.C. (2006), Library 2.0: Service for the Next Generation Library, "Library Journal", Vol. 131, No. 14, p. 40-44.

Chiessi S. (2011), What are Libraries Worth?: a Way to Assess the Impact of Italian Public Libraries on User's Lives and Society, IFLA, https://doi.org/10.1017/CBO9781107415324.004 [accessed: 6.06.2019].

Chymkowski R., Parfianowicz-Vertun W., Ociepa A. (2017), Biblioteki publiczne m.st. Warszawy: diagnoza i rekomendowane zmiany, Warszawa, http://www.wpek.pl/pi/117301_1. pdf [accessed: 6.06.2019].

DeFaveri A. (2005), Breaking Barriers: Libraries and Socially Excluded Communities, "Information for Social Change", 21, http://libr.org/isc/articles/21/9.pdf [accessed: 29.08.2019].

Drzewiecki M. (2011), Biblioteki publiczne i szkolne w procesie ksztattowania edukacji społecznej: wybrane aspekty, [in:] D. Kuźmina (ed.), Bibliologia i informatologia, Warszawa: Polskie Towarzystwo Bibliologiczne Oddział Warszawski, p. 81-87.

Fatyga B. (2014), Rekonstrukcja sensu kategorii uczestnictwo w kulturze, [in:] R. Drozdowski, B. Fatyga, M. Filiciak, M. Krajewski, T. Szlendak, Praktyki kulturalne Polaków, Toruń: Wydawnictwo Naukowe Uniwersytetu Mikołaja Kopernika, p. 9-12.

Frederiksen L. (2015), "Our Public Library": Social Reproduction and Urban Public Space in Toronto, "Women's Studies International Forum", No. 48, p. 141-153.

Gehner J. (2010), Libraries, Low-Income People, and Social Exclusion, "Public Library Quarterly", Vol. 29, Issue 1, p. 39-47.

Główny Urząd Statystyczny (2019), Bank Danych Lokalnych - Kultura - Biblioteki - Biblioteki Publiczne. Warszawa: GUS, https://bdl.stat.gov.pl/BDL/dane/podgrup/tablica[accessed: 6.06.2019].

Goban-Klas T. (2009), Media i komunikowanie masowe. Teorie i analizy prasy, radia, telewizji i Internetu, Warszawa: Dom Wydawniczy PWN.

Ha T. (2018), Forbes Deleted a Deeply Misinformed op-ed Arguing Amazon Should Replace Libraries, "Quartz", https://qz.com/1334123/forbes-deleted-an-op-ed-arguing-that-amazon-should-replace-libraries/?fbclid=IwAR162qOAMit0WbESqlZT4uv0-eQ8BF4EhNjB4vi_-pY0UJJBZDmvQAtvAlM [accessed: 6.06.2019]. 
Knaś P. (2012), Sektor kultury. Ujęcie instytucjonalne i znaczenie gospodarcze, "Badania w Kulturze", http://badania-w-kulturze.mik.krakow.pl/2012/02/22/sektor-kultury-ujecie-instytucjonalne-i-znaczenie-gospodarcze/index.html [accessed: 6.06.2019].

Koontz C.M., Jue D.K., Bishop B.W. (2009), Public Library Facility Closure: an Investigation of Reasons for Closure and Effects on Geographic Market Areas, "Library and Information Science Research", Vol. 31, No. 2, p. 84-91.

Koryś I., Chymkowski R. (2019), Stan czytelnictwa w Polsce w 2018 roku. Wstępne wyniki, Warszawa: Biblioteka Narodowa, https://bn.org.pl/download/document/1553593649.pdf [accessed: 6.06.2019].

Kotnarowski M., Piechocki P. (2019), Co wpływa na zaangażowanie w kulturę?, [in:] T. Płachecki (ed.), Relacje i różnice: uczestnictwo warszawiaków i warszawianek w kulturze, Warszawa: M.st. Warszawa, p. 34-49.

Krajewski M. (2014), Uczestnictwo w kulturze, [in:] R. Drozdowski, B. Fatyga, M. Filiciak, M. Krajewski, T. Szlendak, Praktyki kulturalne Polaków, Toruń: Wydawnictwo Naukowe Uniwersytetu Mikołaja Kopernika, p. 12-19.

Lissowski G., Haman J., Jasiński M. (2011), Podstawy statystyki dla socjologów, Vol. 2: Zależności statystyczne, Warszawa: Wydawnictwo Naukowe Scholar.

Mourdoukoutas P. (2018), Amazon Should Replace Local Libraries to Save Taxpayers Money, http://www.ala.org/yalsa/sites/ala.org.yalsa/files/content/AmazonShouldReplaceLocalLibrariestoSaveTaxpayersMoney.pdf [accessed: 6.06.2019].

Muddiman D., Durrani S., Dutch M., Linley R., Pateman J.,Vincent J. (2000), Open to All? The Public Library and Social Exclusion, Library and Information Commission Research Report 84, The Council for Museums Archives and Libraries, http://eprints.rclis.org/6283/1/lic084. pdf [accessed: 29.08.2019].

Nguyen L.C., Partridge H., Edwards S.L. (2012), Towards an Understanding of the Participatory Library, "Library Hi Tech", Vol. 30, No. 2, p. 335-346.

Paul M. (2018a), Korzystanie z bibliotek jako formy relacji - analiza koncepcji teoretycznej $z$ wykorzystaniem triangulacji metod badawczych, "Przegląd Biblioteczny", Vol. 86, No. 4, p. 531-553.

Paul M. (2018b), Wplyw społeczny bibliotek publicznych. Badanie użytkowników bibliotek wwojewództwie mazowieckim, Warszawa: Cogito.

Pugacewicz I. (2017), Biblioteka Saint Geneviève i jej tożsamość środowiskowa, [in:] A. Mierzecka, E.B. Zybert (ed.), Instytucje kultury jako ośrodki życia społecznego, Warszawa: Wydawnictwo SBP, p. 156-174.

Rószkiewicz M., Perek-Białas J., Węziak-Białowolska D., Zięba-Pietrzak A. (2013), Projektowanie badań społeczno-ekonomicznych. Rekomendacje i praktyka badawcza, Warszawa: Wydawnictwo Naukowe PWN.

Tyszka A. (1981), Partycypacja kulturalna, “Teksty: teoria literatury, krytyka, interpretacja”, Vol. 57, No. 3, p. 137-142.

Usherwood B. (2002), Accounting for Outcomes: Demonstrating the Impact of Public Libraries, “Australasian Public Libraries and Information Services", Vol. 15, No. 1, p. 5-13. 
Williamson M. (2000), Social Exclusion and the Public Library: a Habermasian Insight, "Journal of Librarianship and Information Science", Vol. 32, Issue 4, p. 178-186.

Wojciechowski J. (2005), Biblioteczna wartość naddana, "Przegląd Biblioteczny”, Vol. 73, No. 1, p. 17-29.

Zickuhr K., Rainie L., Purcell K., Duggan M. (2013), How Americans Value Public Libraries in their Communities, Washington: Pew Research Center. 